Radim Pulec

Prešovská univerzita v Prešove
Kiedy myślimy Rodzina..., red. M. Duda,

K. Kutek-Sładek, Kraków 2016, s. 89-94

(Praca Socjalna w Teorii i Działaniu, 2).

\title{
Úloha rodiny u ctihodného starce Porfyria
}

\author{
Rola rodziny w nauczaniu czcigodnego starca Porfyria \\ The role of the family venerable old man Porfyrios
}

Abstract: Venerable old man Porfyrios
spoke about the christian values not only
with words, but with his whole live. We
can find his spiritual link only from the
testimony of people close to him who
turned to him with a request for father-
ly advice in matters of faith and chris-
tian life. One of its main themes was the christian family. Porfyrios blessed the establishment of the family and gave advice to parents in raising their children. The lecture contains the main ideas of his relationship to the family.

Keywords: family, children, prayer, motherly love, holy life

\section{Rodina u ctihodného starce Porfyria (+1991)}

Starec Porfyrios byl kanonizován Posvátným synodem konstantinopolského patriarchátu 27. listopadu 2013. Poručil svoji duši Pánu v athoském skitu Kavsokallivita dne 2. prosince $1991^{1}$. Po třech letech přenesli poslušníci jeho ostatky ze hřbitova na neznámé místo, protože si to tak starec před smrtí přál, a navíc je zavázal, aby nikomu to místo neprozradili. Nechtěl být totiž uctíván jako světec, odmítal představu, že by mohl být kanonizován².

O křestanských hodnotách vypovídal jak svým životem, tak i myšlenkami, které zapsaly jeho duchovní děti. Otec Porfyrios nenapsal a nevydal žádnou knihu. Mezi zachovalými soukromými písemnostmi osobní povahy vyniká dopis

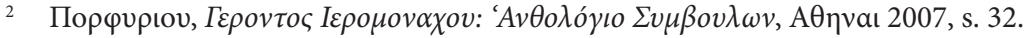


na rozloučenou, publikovaný v knihách o jeho životě3. Světcův duchovní odkaz tak nalezneme pouze ve svědectví jeho posluchačů a jemu blízkých lidí. Jsou to svědectví oslovující a hluboká.

Již za svého života byl ctihodný starec považován za světce. Nejenom proto, že jeho modlitby měly uzdravovací sílu, ale též pro jeho prozřetelnost, kterou projevoval vždy nečekaně a doslova tím šokoval své okolí. Vzácným byl také jako duchovní pastýr všech, jež se k němu obraceli s prosbou o otcovskou radu v otázkách víry a pravého kř̀estanského života. Jedním z jeho hlavních témat byla křestanská rodina.

K založení štastné křestanské rodiny otec Porfyrios žehnal všem, kteří k němu přicházeli. Podle svědectví osob ze starcova okolí např́iklad poradil jednomu mladíkovi, aby si nehledal nevěstu v hlavním městě, ale daleko od něj v malé vesničce. Poslechl a nevěstu si opravdu našel ve vesnici daleko od městského ruchu, oženil se s ní a byli spolu štastní. Otci Porfyriovi za tuto radu mnohokrát děkoval. Pochopil, že světské představy o budoucí manželce jej zbytečně svazovaly ${ }^{4}$.

Jednou se otci Porfyriovi svěřil manžel se svými těžkostmi, protože si špatně vybral svou životní družku. Starec mu dal za pravdu: „Udělal jsi chybu, kterou již nemůžeš napravit! Lze však zmírnit následky této chyby. Bud’ trpělivý a Bůh ti pomůže a budeš i tak velice štastný “5

Jindy zase poradil otec Porfyrios jednomu ze svých duchovních synů, kterému manželka vyčítala, že chodí příliš často na bohoslužby: „Nehádej se s ní. Když se ale budeš vracet $\mathrm{z}$ chrámu domů, pohlad’ ji po tvárích a polib ji. Uvidíš, že se jí to bude líbit a zapomene na to, co ti vyčítala".

Svatý Porfyrios radil mladým manželům, jak mají vytvářet příjemnou rodinnou atmosféru a pohodu. Byl při tom vždy konkrétní. Např́klad jedné mladé paní řekl: „Nemluv tolik, když vidíš, že má manžel velké starosti. Modli se za něj a pros i své blízké, aby se za ně modlili. Svými řečmi mu jen starosti přiděláš. Když nenajde u tebe teplo a útěchu, bude ji hledat jinde ${ }^{\text {“7 }}$.

Svatý Porfyrios nikdy nesouhlasil s žádným argumentem, který vedl k tomu, aby mladí manželé neměli děti. Když jim je Bůh nedá přirozenou cestou, mohou si děti adoptovat.

Mladému knězi, který se u otce zpovídal, řekl při jednom přátelském rozhovoru: „Prosím tě, říkej mladým, aby se nebránili mít děti. Je to veliký hřích,

\footnotetext{
A. Kaliatsos, Starec Porfýrij, Človeče, vieš kam kráčaš?, Atény 2000, Prešov 2008.

Tamtéž, s. 355.

A. Kaliatsos, Starec Porfýrij..., dz.cyt., s. 357.

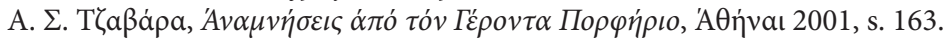

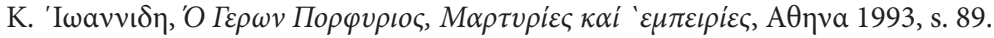


když nechtějí mít děti. Pokračuj v tom a říkej jim jasně, že z hlediska křest’anského není žádný důvod se vyhýbat plození děti'“8.

Podle názoru otce Porfyria děti jedinečným způsobem pomáhají stmelovat manželské soužití. Mnoho životních příběhů dalo starci za pravdu. Jako příklad pro to můžeme uvést svědectví jedné rodiny z blízkosti otce Porfyria, která by se byla rozpadla, kdyby jim Bůh nedal alespoň jednoho potomka. Starec manželům po mnoha letech řekl: „Kdyby se vám nenarodilo dítě, určitě byste se rozvedli a jen Bůh ví, co by s vámi bylo. Proto jsem vám kdysi řekl, abyste měli děti. Zachránili jste tak svůj manželský svazek. Myslete na to stále. Vaše dítě vám i v budoucnosti bude správně ukazovat vaši životní cestu“9.

Svatý Porfyrios často mluvil o nedostatku lásky, který je charakterizuje naši dobu: je příčinou osamocení, smutku, nejistoty, zmatku a strachu. Říkal: „Běžte se podívat do dětského domova a najdete tam ubohé, opuštěné děti. Podobají se jehňátkům bez maminky. Čekají, až je někdo navštíví a zahřeje je trochou lásky. Běžte se podívat, jak prahnou po lásce.“ Svoje úvahy uzavíral myšlenkou: „Děti, jež mají své rodiče, ale nejsou od nich milované, se nijak neliší od sirotkü “10.

Ptali se jedni rodiče otce Porfyria, co mají dělat, když je jejich dětátko stále roztř̌esené a plné bázně. - „Můžete si za to sami. Vaše vzájemné špatné vztahy mu způsobily toto trauma, které ho bude provázet celý život" ${ }^{\text {"11 }}$.

Svatý Porfyrios upozorňoval rodiče, aby si dávali pozor na své chování, i když mají dojem, že je děti neposlouchají. „Jsou přece ještě maličké.“ „Není to pravda. Podívejte se na malé dítě, jak si prohlíží neznámého člověka. Za dvě vteřiny pozná jeho charakter, zdali je dobrý, nebo špatný“"12.

Gynekologům radil: „Ŕíkejte nastávajícím maminkám, jakou milost jim Bůh prokázal, že se jim narodí dětátko. Od okamžiku početí mají ještě jeden život. At’ s dítětem hovoří, hladí jej, když ho ještě nosí pod srdcem. Vše již cítí a vnímá. At̉ se za něj modlí. Podobně jako narozené dítě cítí i nenarozené nedostatek mateřské lásky. Prožívá s matkou její averze, starosti, hněv. Jeho duši poznamenají rány, které jej provázejí celý život. - Naopak ušlechtilé mateřské city a matčin svatý život posvěcují dítě od okamžiku početí. Totéž platí o otci“"13.

Svatý Porfyrios také tvrdil, že zájem dobrého otce o své dítě nemůže přestat, ani když vyroste a je zatvrzelé nebo se vzbouří, neposlouchá a chová se nepřátelsky. Dokáže tím nejen dovednost v oblasti lidských vztahů, ale projeví hlav-

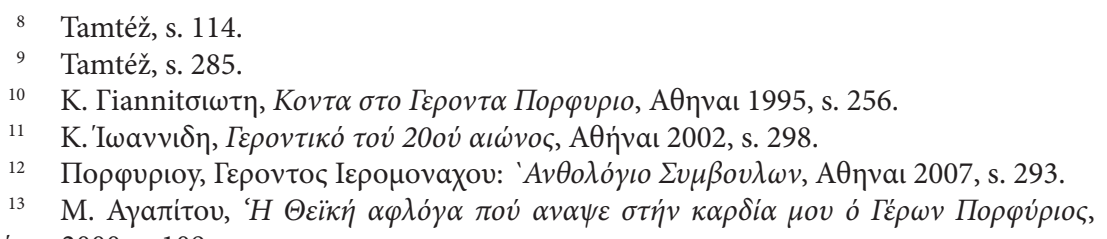


ně lásku dobrého otce, nebot děti, než dosáhnou dospělosti, dělají nerozumné a hloupé věci a provokují své rodiče, zvláště otce.

Otec někdy přitvrdí a z nedostatku soudnosti zapomíná své místo dobrého otce a jedná jako policista. Působí dítěti nenapravitelné zlo. Když se nedospělé dítě vcítí do svého otce, vidí, že dělá nepochopitelné ústupky a dokáže být nesmírně otcovsky trpělivý, tehdy toto dítě až do své smrti bude nosit jméno svého otce v srdci a ř́kat: „Můj táta byl svatý. Poznal jsem to, když jsem mu dělal v mládí naschvály" ${ }^{\prime 14}$.

Rodiče jednoho neposlušného a těžko zvládnutelného dítěte navštívili otce Porfyria a vylíčili mu své problémy. Prosili jej o radu. Řekl jim, aby dávali dobrý pozor na své chování. Rodiče se však vrátili k svým problémům s dítětem, ale starec pokračoval v líčení křestanských povinností, které jako rodiče mají. Tehdy jej neštastní rodiče upozornili, že k němu nepřišli kvůli sobě, ale kvưli problémům se svým dítětem: „To, co nám říkáte, známe od mládí z hodin náboženství“. Otec Porfyrios jim na to odvětil: „Nechápete, že celou tu dobu mluvím o vašem dítěti? Záchrana vašeho dítěte je možná pouze tehdy, změníte-li své chování. Nikoliv teoreticky, ale vskutku spočívá ve svatosti vašeho života“. Nakonec dodal: „Musíte s tím začít ihned, jestli svoje dítě opravdu milujete“15.

Jiná matka, jež měla těžkosti se svými dětmi, se na otce Porfyria obrátila s otázkou: „Otče, naše děti se narodily už takové, nebo za to mohou naše chyby?“ Starec odpověděl: „Mohou za to vaše chyby. Avšak ovlivňují je též jejich přátelé, kteří žijí životem hříšným a posmívají se Kristu“16. „Ani jednou vás nesmí děti slyšet, jak se hádáte nebo zvyšujete hlas jeden na druhého.“ - „Je to možné dokázat, otče?“ - „Ano, jistěže je to možné. A jak jsem vám řekl ani jednou! “17.

Svatý Porfyrios svěril svému duchovnímu synovi: „Jsi zbožný. Rád bys tuto svoji zbožnost a víru předal blízkým lidem kolem sebe. Myslíš, že se ti to povede? Nepovede, nebot lidé to nepřijmou. Řekneš jednomu, aby udělal to či ono. Neudělá to, protože jsi mu to nařídil... Když tě ale uvidí, že to sám děláš, možná, že tě bude napodobovat, protože si řekne: ,Když to dělá on, zkusím to také'“.

A pokračoval: „Modli se ke Kristu slovy - ,Můj Pane, osvět', smiluj se a provázej tohoto člověka a smiluj se nad ním'. - Opakuj stále tuto modlitbu, Kristus mu pak pošle čisté myšlenky. Pokaždé, když řekneš např́iklad: ,Pane, smiluj se nad mým dítětem, 'tvé dítě dostane od Krista dobrou myšlenku. Čím více a další.

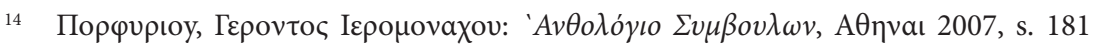

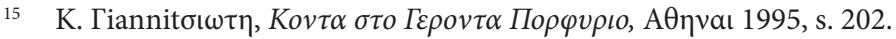

16 Tamtéž, s. 124.

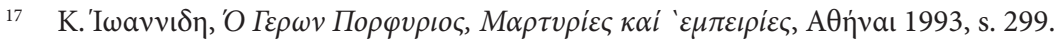


se budeš takto modlit, tím více čistých myšlenek dostane tvé dítě. Tvé dítě je nyní podobné nezralému ovoci, pomalu bude dozrávat a postupně bude takovým, jakým ho chceš mít. Mám to vyzkoušené. Osobně jsem se přesvědčil, že může člověk tímto způsobem řešit jakýkoliv problém. Protože jiné způsoby řešení problémů člověk přijímá instinktivně; ve většině př́ípadů nepomáhají...“.

Jako příklad uvedl otec Porfyrios rodiče, jejichž dcera sešla z cesty Boží. Chování a způsob života způsobila velmi napjatá situace u nich doma. Jednou otec ztratil hlavu a rozohnil se takovým zpo̊sobem, že dceři nejenom spílal, ale chtěl ji i zabít. Uklidnil se však a přišel požádat s manželkou otce Porfyria o radu. Starec mu řekl: „Nechápeš, co se stalo? Tvé dítě sebral dábel a dělá si s ním, co chce. Nic tady nepomůže. Jedině modlitba. Modlete se oba za svoji dceru, jen s ní o tom nemluvte... Až zase přijde pozdě domů, jak si zvykla, řekněte: ,Jídlo máš v lednici. Posad' se, ohřeju ti ho.' Dcera přitom sestoupí z výšin a pomyslí si, kde se vzala u těch mých barbarských rodičů ta dobrota? - Vy ale pokračujte v modlitbách za ni. Uvidíte, že sama přijde na to, jak moc je špatné, co dělá a s kým se stýkác.

Opravdu po nějaké době dívka oznámila rodičům, že se definitivně rozešla se špatnými lidmi, kteří ji strhli na scestí. Navrátila se k normálnímu způsobu života a zachránila se ${ }^{18}$.

„Za své děti je třeba se modlit“, říkal svatý Porfyrios rodičům, kteří se mu svěřovali s problémy, jež měli při výchově svých potomků. Modlitba je medium, jež zachraňuje narušené lidské vztahy a zvláště je potřebná v rodině. Modlitba rodičů za děti a dětí za rodiče dělají rodinu rodinou křestanskou a vedou její členy po cestě pozemské do nebeského království.

\section{Bibliografia}

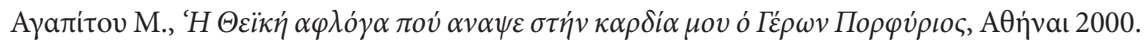
Bible, Český ekumenický překlad, Biblické dílo Ekumenické rady církví v ČSR, Praha 1987, 3. doplněné a přeprac. vydání.

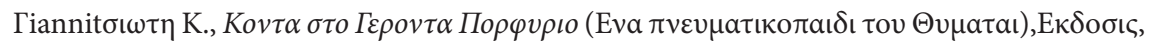

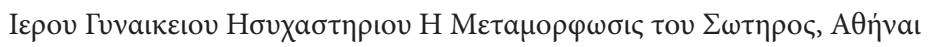
1995.

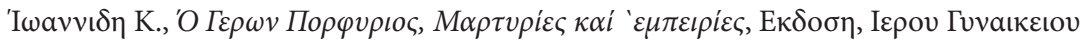

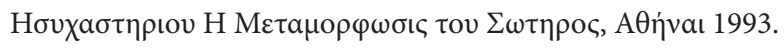

Kaliatsos A., Starec Porfýrij, Človeče, vieš kam kráčašs?, Atény 2000, z ruštiny přeložil jeromanch Alexij (Oleksa), Prešov 2008.

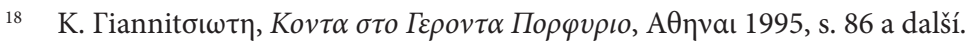




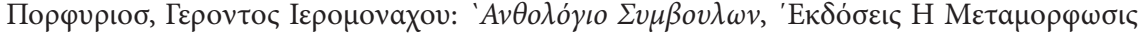

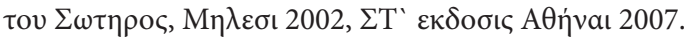

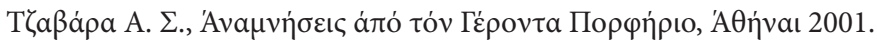
www.fanarion.blogspot.com/2013/11. 